\title{
ダム基礎の透水性とルジオン值 \\ PERMEABILITY AND LUGEON VALUES OF DAM FOUNDATIONS
}

\author{
山口嘉一*・松本徳久** \\ By Yoshikazu YAMAGUCHI and Norihisa MATSUMOTO
}

\begin{abstract}
In surveying the permeability of dam foundations, Lugeon water test is usually adopted and the permeability is evaluated by Lugeon value $(L u)$. The curve between pressure and rate of water injection ( $p-q$ curve) is drawn by using the test results and Lugeon value is obtained from the slope of straight line part of $p-q$ curve. However, quite a few $p$ - $q$ curves which have various shapes except the straight line, are obtained when Lugeon water tests are performed at fields. Therefore, in order to interpret the results of Lugeon water tests accurately the authors performs the following things: (1) $p-q$ curves obtained from Lugeon water tests are classified into several categories, (2) causes of several $p-q$ curves classified in (1) are summarized, (3) the methods to determine the accurate Lugeon value from each $p$ - $q$ curve are illustrated.

Keywords : Lugeon water test, $p-q$ curve, Lugeon value, seepage analysis
\end{abstract}

\section{1.はじめに}

ダムの設計において, 基礎地盤の透水性を把握するこ とは非常に重要な課題の 1 つである. ダム基礎地盤に対 する原位置透水試験法としては, 一般にボーリング孔を 利用するルジオンテストが用いられている.なお, 透水 性は, 試験孔に数段階の圧力で注水し, 各段階ごとの有 効注入圧力 $p$ と試験区間長 $1 \mathrm{~m}$ 当たりの注入量 $q$ から 注入王力-注入量曲線（以下, $p-q$ 曲線之称す）を描き, それに直線関係があることを確認した後で注入圧力 10 $\mathrm{kgf} / \mathrm{cm}^{2}$ 時の試験区間長 $1 \mathrm{~m}$ 当たりの注入量 $(l / \mathrm{min} / \mathrm{m})$ として表現されるルジオン值 $L u$ によって評価される.

この試験法には,「ルジオンテスト技術指針・同解 説」) (以後, 技術指針と称す) という指針があり，お のおののダム基礎の透水性を統一された試験方法により 調査する方向が目差されている.このように同一の試験 方法により得られた結果を蓄積することは, 今後のダム 基礎の透水性調査に大いに役立つものである.しかし， このような同一の試験方法に従ってルジオンテストを実

* 正会員 建設省土木研究所フィルダム研究空研究員 ( 凤 305 茨城県つくば市大字旭一番地)

** 正会員 工博 建設省土木研究所フィルダム研究室室長 (同上)
施した場合でも, 亀裂の少ない硬岩地盤では結果の解析 に際して問題が発生する可能性は少ないが, 亀裂が発達 した硬岩地盤や岩自体の変形性が大きい軟岩あるいは砂 磷地盤では, 結果として得られる $p-q$ 曲線には直線関 係がないものや, 昇圧段階と降圧段階では異なった経路 を通るものもかなり含まれており，ルジオン值の決定が 困難になることがしばしば見受けられる，菅原 ${ }^{2)}$ が，技 術指針が出された後, 数種類の $p-q$ 曲線を多くの技術 者に与えて算出されたルジオン值は, 技術者の経験年数 によらずかなりばらついていたという結果は, 上記のこ とを端的に表わした例である.この試験方法は, Lugeon $^{3)}$ が 1933 年に提唱して以来, 基準注入圧力 10 $\mathrm{kgf} / \mathrm{cm}^{2}$ 時にどの程度の注入量になるかを測定する定性 的なインデックス試験の性格が強い. しかし, ルジオン テストの結果得られる $p-q$ 曲線は地盤の水理特性の反 映であり, 適切な解析を行うことにより多くの情報が得 られる可能性がある。 そこで本論文においては, 種々の 形状の $p-q$ 曲線の発生する原因を分析するとともに, いかにダム湛水後の基礎浸透流を支配する透水性を表わ すルジオン值を決定すればよいかを検討する．このルジ オン值は, もはや従来の定性的な透水性の指標とみなさ れているものではなく定量的な指標になるものである. さらに，ルジオンテストを注水式の定水位透水試験と考 


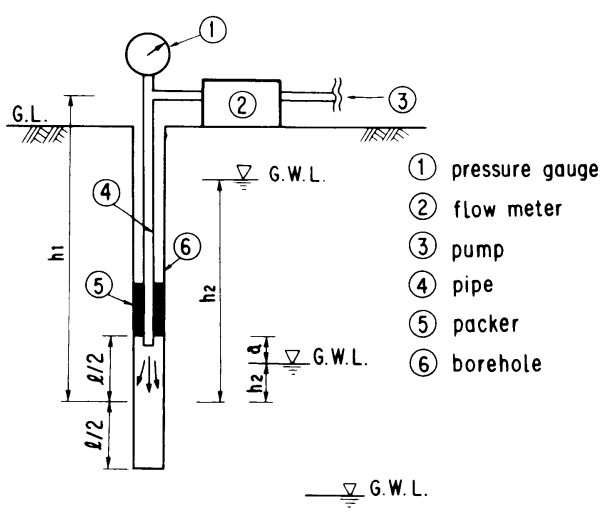

Fig. 1 Schematic view of Lugeon water test.

え, このルジオン值を Darcy 則に基づいて透水係数に 変換し, それを浸透流解析の入力物性值とすることでダ 厶湛水に伴う漏水量を現状よりも正確に求めることもで きる。

\section{2. ルジオンテストの解析方法}

\section{（1）有効注入圧力}

有効注入王力は，技術指針にも示されているとおり， 口元圧力を試験区間中央から口元圧力計までの静水圧, 地下水圧および注入管内抵抗による損失水頭により補正 して求める (Fig. 1 参照). 具体的な注入圧力の求め方を, 地下水位と試験区間の位置関係に従って以下に示す ${ }^{4), 5)}$.

(1) 地下水位が試験区間より上にある場合

$$
p=p_{0}+\gamma_{w}\left(h_{1}-h_{2}-h_{3}\right) \quad\left(\mathrm{kgf} / \mathrm{cm}^{2}\right)
$$

ここに, $p$ は有効注入圧力 $\left(\mathrm{kgf} / \mathrm{cm}^{2}\right), p_{0}$ は口元圧力 $\left(\mathrm{kgf} / \mathrm{cm}^{2}\right), h_{1}$ は圧力計から試験区間中央までの標高 差 $(\mathrm{m}), h_{2}$ は地下水面から試験区間までの水頭 $(\mathrm{m})$, また，被圧水の場合にはそれに相当する水頭 $(\mathrm{m}), h_{3}$ は注入管内抵抗による損失水頭 $(\mathrm{m}), \gamma_{w}$ は水の単位体 積重量 $\left(1 \mathrm{tf} / \mathrm{m}^{3}=0.1 \mathrm{kgf} / \mathrm{cm}^{2} / \mathrm{m}\right)$ である.

なお, 損失水頭 $h_{3}$ は, 一般に次式により算出される ${ }^{11}$. $h_{3}=\alpha Q^{2} L$

ここに, $Q$ は全注入流量 $(l / \mathrm{min}), L$ は口元圧力計か ら試験区間までの注入管長 $(\mathrm{m}), \alpha$ は試験によって求 めることが望ましいが, 試験によらないときは $7 \times 10^{-5}$ $\left(\min ^{2} / l\right)$ とされている.

（2) 地下水位が試験区間より下にある場合 $p=p_{0}+\gamma_{w}\left(h_{1}-h_{3}\right) \quad\left(\mathrm{kgf} / \mathrm{cm}^{2}\right)$

(3) 地下水位が武験区間中にある場合

$$
\left.\begin{array}{l}
p=p_{0}+\gamma_{w}\left\{\left(h_{1}-h_{2}-\frac{a^{2}}{2 l}\right)-h_{3}\right\} \quad\left(\mathrm{kgf} / \mathrm{cm}^{2}\right) \\
a=l-h_{2} \quad(0 \leqq a \leqq l)
\end{array}\right\}
$$

\section{（2）ルジオン值の決定}

ルジオンテストの結果から,有効注入圧力 $p\left(\mathrm{kgf} / \mathrm{cm}^{2}\right)$

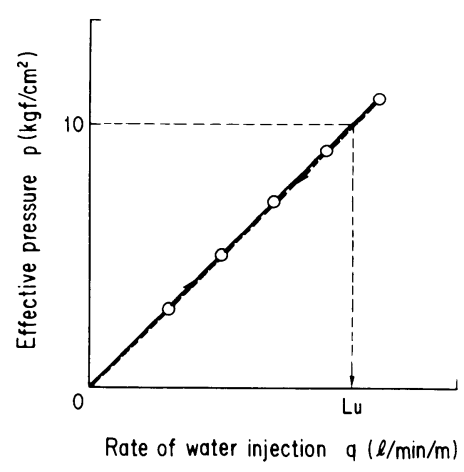

Fig. $2 p$ - $q$ curve.

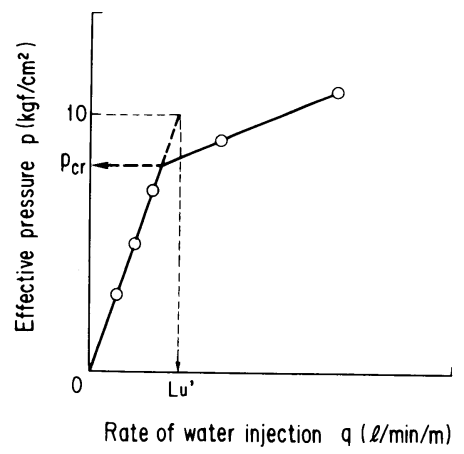

Fig. $3 p$ - $q$ curve with critical pressure.

を縦軸に，そのときの試験区間 $1 \mathrm{~m}$ 当たり，1 分間の定 常注入量 $q(l / \mathrm{min} / \mathrm{m})$ を横軸にとった $p-q$ 曲線を描 く(Fig. 2 参照). ルジオン值 $(L u)$ は，この $p-q$ 曲線 に直線関係があることを確認した後, 有効注入圧力 10 $\mathrm{kgf} / \mathrm{cm}^{2}$ 時の注入量 $(\mathrm{l} / \mathrm{min} / \mathrm{m})$ として求める. 注入圧 力を段階的に上げながら試験をする際，Fig. 3 に示すよ うにある注入圧力のところから急激に注入量が増大する 場合がある．この注入量が急増するときの有効注入圧力 を限界圧力 $p_{c r}$ とよぶ. 限界圧力が有効注入王力 10 $\mathrm{kgf} / \mathrm{cm}^{2}$ 以下で発生した場合は, $p-q$ 曲線の限界圧力以 下の直線を延長することにより注入圧力 $10 \mathrm{kgf} / \mathrm{cm}^{2}$ 時 の注入量を求めてルジオン值とする.なお，このルジオ ン値は換算ルジオン值 $\left(L u^{\prime}\right)$ として通常のそれとは区 別しなければならない.

\section{3. 浸透流解析の概要}

本論文においては, 飽和一不飽和浸透流解析をしばし ば用いる，そこで，その概要を示しておく．まず，解析 の基本方程式 ${ }^{6)}$ は以下に示すとおりである.

$\operatorname{div} k(\theta) \vec{\nabla}(\psi+z)=\left(C(\theta)+\varepsilon S_{s}\right) \frac{\partial \psi}{\partial t}$

$\varepsilon=\left\{\begin{array}{l}0: \text { 不飽和領域 } \\ 1: \text { 飽和領域 }\end{array}\right.$ 
ここに, $k(\theta)$ は透水係数テンソル, $\psi$ は圧力水頭, $\theta$ は体積含水率, $C(\theta)(=\partial \theta / \partial \psi)$ は比水分容量, $S_{s}$ は比貯留係数, $z$ は鉛直座標, $t$ は時間である.

浸透流解析用の解析モデルは, Fig. 4 に示す軸対称モ デルである．なお，モデル化の範囲は試験孔からの注水 に対してモデルがほぼ無限の広がりをもつ透水性媒体と みなせる程度としだ!

また，浸透流解析の実施に際し，何も言及しない場合 には，モデル解析ということも考慮して以下の仮定を満 足するものとする.

(1) 飽和時の透水係数 $k_{0}$ は $1.0 \times 10^{-4} \mathrm{~cm} / \mathrm{s} \quad(10 \mathrm{Lu}$ 程度）とする.

(2) 比貯留係数 $S_{s}$ は $1.0 \times 10^{-7} \mathrm{~cm}^{-1}$ とする.

(3) 間隙率 $n$ は 0.2 とし, 最小容水量（土の吸着水 のように浸透流によって移動し得ない体積含水率の 値） $\theta_{r}$ を 0.0 , 有効体積含水率（土の間隙比から工 ントラプト・エアなどの空気の占める割合を除いた 値） $\theta_{e}$ を間隙率と同じ 0.2 とする.

(4) 不飽和特性のうち, 不飽和透水係数を飽和透水係 数で除した比透水係数 $K_{r}$ と体積含水率 $\theta$ の関係を 表わす関数として Irmay の提案式8) を採用する.

(5) 不飽和特性のうち, 体積含水率 $\theta$ と負の圧力水 頭 $\psi$ の関係を表わす水分保持曲線は, 湿潤過程と 排水過程の間のヒステリシスを考慮しない.

(6) 水分保持曲線は $(\theta=0.2, \psi=-0.0 \mathrm{~m}),(\theta=$ $\left.1.0 \times 10^{-6}, \psi=\psi_{0}\right),(\theta=0.0, \psi=-17.5 \mathrm{~m})$ を結 ぶ折線で表わし， $\theta=1.0 \times 10^{-6}$ における圧力水頭 $\psi_{0}$ を $-1 \mathrm{~m}$ とする.

以上(3)から(6)の仮定に基づく不飽和特性曲線を Fig. 5 に示す.

\section{4. $\boldsymbol{p}-\boldsymbol{q}$ 曲線の分類}

ルジオンテストの結果の解析方法についてまとめる前

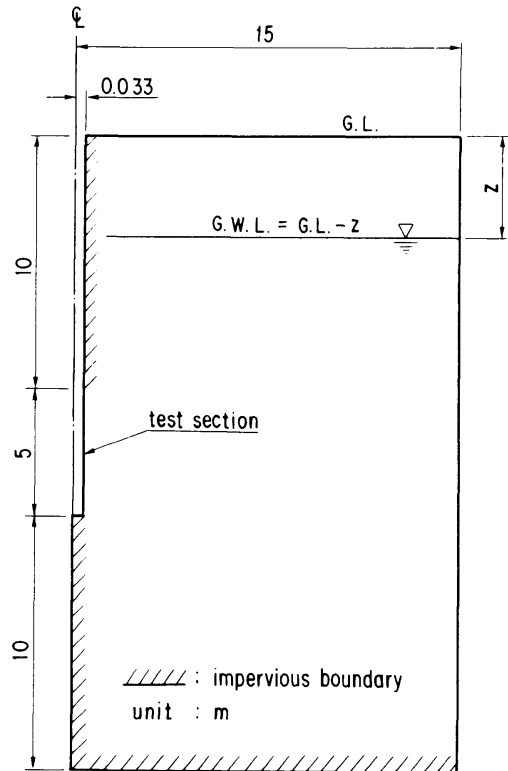

Fig. 4 Analytical model.

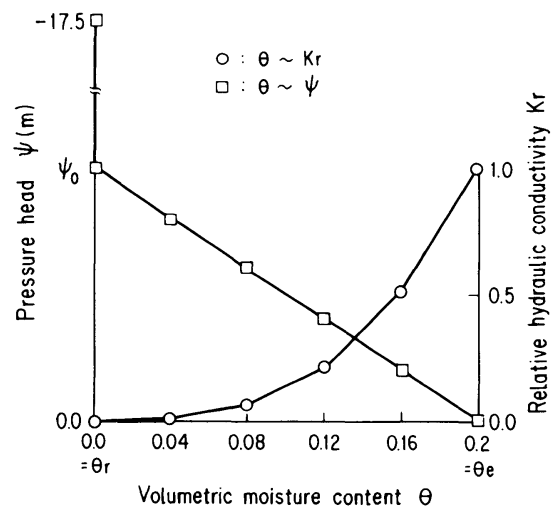

Fig. 5 Unsaturated properties.

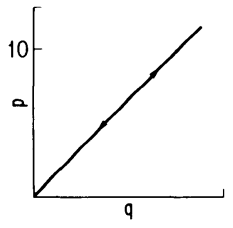

(a)

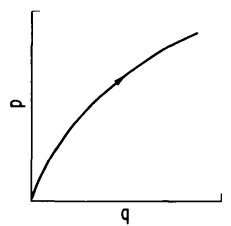

(f)

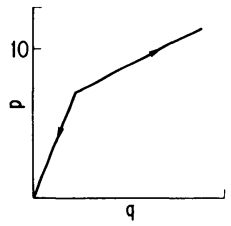

(b)

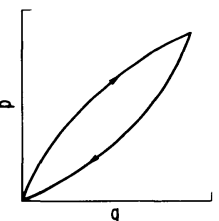

(g)

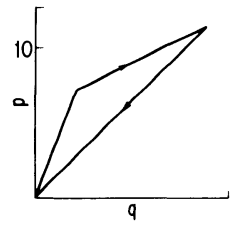

(c)

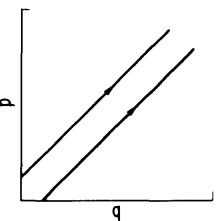

(h)

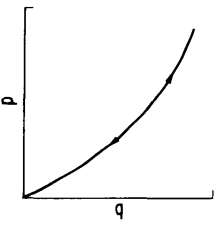

(d)

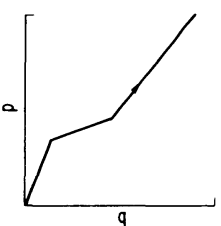

(i)

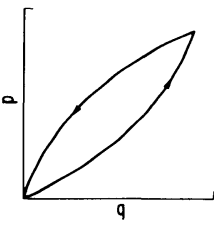

(e)

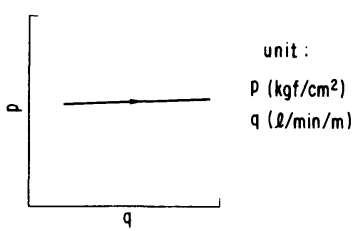

(i)

Fig. 6 Patterns of $p$ - $q$ curves. 
に, $p-q$ 曲線をその形状に応じて Fig. 6 に示すように 分類する．また，以下では，各形状の $p-q$ 曲線の発生 原因をとりまとめ, その影響度合を検討し, 最終的には ダム湛水に伴う基礎浸透流を支配する透水性を表現する ルジオン值をいかに求めるかを示す.

\section{5. 原点を通る直線型 $\boldsymbol{p}-\boldsymbol{q}$ 曲線}

\section{（1）限界圧力が認められない場合}

これは,Fig.6（a）に示すように昇圧段階と降圧段 階で全く同路をたどる原点を通る直線より成り，かつ途 中で限界圧力が認められない $p-q$ 曲線である.この型 の $p-q$ 曲線は, 試験対象地盤の種類にかかわらず，注 水時の地盤変形はなく試験孔からの水の流れが層流であ ることにより得られるもので，ルジオン値はこの直線よ り求めればよく, 何ら問題はない。 なぜならば，ダムの 湛水に伴い基礎地盤中に発生する浸透流の動水勾配はか なり小さく，水は層流かそれに近い状態で流れているか らである，このことは，末吉・大村ら ${ }^{9)}$ が節理性岩盤モ デルによる解析で, 松本・山口ら ${ }^{10)}$ が多孔質媒体モデ ルによる解析で明らかにしている.

\section{（2）限界圧力が認められた場合}

これは, Fig.6 (b )，（c）に示すように限界圧力が 有効注入圧力 $10 \mathrm{kgf} / \mathrm{cm}^{2}$ 以下で認められるものの昇圧 段階の限界圧力以下が原点を通る直線となっている $p-q$ 曲線である。 なお, 限界圧力が有効注入圧力 10 $\mathrm{kgf} / \mathrm{cm}^{2}$ 以上である場合は, 昇圧段階のみに着目して

（1）に属するものとする.

この型の $p-q$ 曲線においても（1）と同様の理由か ら限界圧力以下の直線部を外挿することにより換算ルジ オン值を求めればよい. 限界圧力以上の $p-q$ 曲線から ルジオン值を求めると透水性の過大評価になる. ダム湛 水に伴う基礎の浸透破壊については別途厳密な評価を行 わなければならないが，よほど限界圧力が小さくない限 り限界圧力以下の $p-q$ 曲線から求めたルジオン值が真 の透水性を表わしていると考えても問題はない，限界圧 力は急激な注入量の増加により認定することができる が，この原因は，有効注入圧力の増加に伴う試験区間周 辺地盤における既存の水みちの拡大あるいは新しい水み ちの形成にある。しかし，明瞭な屈曲点が認められた $p-q$ 曲線には，昇降圧段階同路のもの（Fig. 6（b) 参 照）と異路のもの（Fig.6（c）参照）が存在する. 前 者の場合,地盤の破壊には至っていないと考えられるが, 技術指針でも示しているとおり，透水性の屈曲点という 解釈でこの点において限界圧力を決定する.

なお,ルジオンテストの結果の解析以前の問題として, 遮水用パッカと孔壁のなじみが悪いためパッカと孔壁の 境界部から漏水が発生したり, パッカ長が十分でないた
め注入水がパッカ直上部の孔内に吹き出したりして, 地 盤の真の透水性や限界圧力を把握できないことがあるの で注意を要す.

\section{6. 逐次流量減少型 $\boldsymbol{p}-\boldsymbol{q}$ 曲線}

\section{（1）発生原因}

これは，Fig.6（d），（e）に示すように昇圧段階に おける初期接線勾配直線に比べて流量が逐次減少傾向に ある $p-q$ 曲線のことで, 昇降圧段階同路のもの (Fig. 6

（d）参照）之昇降圧段階異路のもの (Fig.6 (e ) 参照) に分類できる.なお，昇降圧段階異路のものは，同じ注 入圧力であれば昇圧段階の注入量の方が降圧段階のそれ よりも大きいと考える.この型の $p-q$ 曲線が発生する 原因を以下にまとめる.

(昇降圧段階同路)

(1) 試験孔から地盤への水の流れが乱流である場合.

(2) 注入管内抵抗に伴う損失水頭 $h_{3}$ による有効注入 圧力の補正を行っていなかったり，行っていても損 失水頭 $h_{3}$ を過小評価している場合.

(3) 地下水面下の試験において, 注水に伴い地下水面 が上昇するため有効注入圧力が減少し, $p-q$ 曲線 が直線関係からずれる場合、ただし，この場合の $p-q$ 曲線が必ずしも逐次流量減少型になるとは限 らず, 逐次流量増加型（7. 参照）になる可能性も ある．この点については，以下で詳しく検討する。

(4) 地下水面上の試験においては，地盤中に注入され た水がポテンシャル流ではなく重力流であること， 地盤の不飽和特性等の影響により直線型 $p-q$ 曲線 が得られない場合.この点についても以下で詳しく 検討する.

(昇降圧段階異路)

(1) 試験孔掘削時に発生するスライムの洗净不足や試 験水中の浮遊物により試験孔周辺地盤の目詰りが助 長される場合.

(2) ある圧力段階における水の流れが定常にならない うちに次の圧力段階に移行する場合.

\section{（2）昇降圧段階同路の場合の詳細検討}

a) 乱流の影響 ルジオンテストにおける試験孔か らの水の流れは放射流となるため，試験孔周辺に大きな 動水勾配が発生する. よって, 亀裂性岩盤や粒径の大き い砅層地盤における試験では, 注入された水の流れが層 流ではなく流水抵抗の大きい乱流となる，そのため，同 注入圧力でも層流を想定した場合よりも注入量が小さく なり，かつその傾向は注入圧力が大きくなればなるほど 強くなる．しかし，昇降圧段階での差はない。その結果， 逐次流量诚少型で昇降圧段階同路の $p-q$ 曲線が得られ る.このルジオンテストにおける乱流現象の存在は, 
Kutzner $^{11)}$, Ewert ${ }^{12)}$, Houlsby ${ }^{13)}$, Lancaster-Jones ${ }^{14)} ら$ によっても指摘されている.

一方，ダム湛水に伴う基礎地盤内の浸透流は，前述し たとおり，層流あるいはそれに近い流れである.よって， ルジオンテストの結果に乱流の影響が及ぶ可能性のある 地盤では, 高粘性流体を用いて試験を行う ${ }^{15), 16)}$ か, 水 によりきわめて低圧力下での試験を行うことにより層流 状態を達成したうえでルジオン值を決定することが望ま れる.さらに，地質状況をよく観察し，ダム湛水に伴う 基礎地盤内の浸透状況も併せて推論しておくことも重要 となってこよう.

なお，層流状態のルジオン値を得る対策のうち前者の 高粘性流体を用いる方法では粘性の増加が, 流れの状況 を決定する無次元量であるレイノルズ数の低下に 2 乗の 効果があるのに対して, 後者のきわめて低圧力の水を用 いる方法では注入圧力低下のレイノルズ数低下に与える 効果は 1 乗でしかない(17).このことは, 松本・山口ら ${ }^{16)}$ の現場実験においても明らかとなっている. よって, 乱 流が発生しやすい高透水性地盤では, 高粘性流体を用い た方が層流状態の実現が容易である.

b）損失水頭の影響 注入管内抵抗による損失水頭 $h_{3}$ の補正の有無が有効注入圧力測定精度に大きな影響 を与えることは，多くの研究者によって指摘されてお $り^{11), 18)}$, 技術指針の中でも補正の必要性を明記している. また, $h_{3}$ が注入量の 2 乗に比例することもあり損失水 頭の無補正は逐次流量減少型の $p-q$ 曲線の発生の原因 となる. いま, 損失水頭の無補正が得られるルジオン值 の精度に与える影響を試算してみる. 有効注入圧力 10 $\mathrm{kgf} / \mathrm{cm}^{2}$ で注水した際, 損失水頭を補正した場合としな い場合で得られるルジオン值の誤差が $\beta$ 以下となる条 件は, 式 ( 1 ) （4) より次式として求めることができ る.なお，得られるルジオン值は，明らかに損失水頭を 補正しない場合の方が小さい.

$L u^{2} L \leqq 5.7 \times 10^{4} \times \beta$.

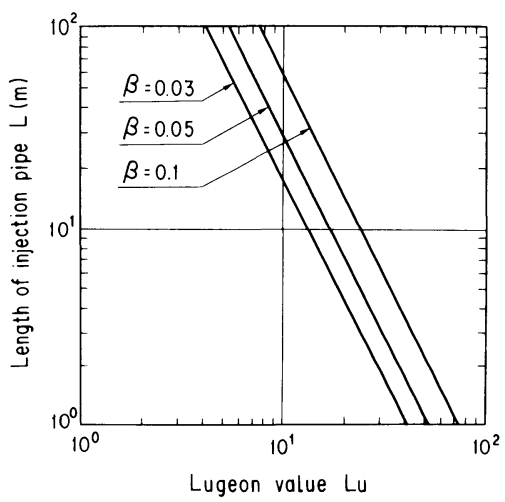

Fig. 7 Effect of head loss $h_{3}$.
ここに, $L u$ は損失水頭を補正した場合のルジオン值で ある。

式（6）中の $\beta$ に $0.03,0.05,0.1$ を代入した場合 の条件式を Fig. 7 として図化した.

損失水頭を正確に知る方法には，実際に使用する注入 管を用いて損失水頭に関する事前実験を行うか, 試験区 間内に間隙水圧計を設置して水頭損失後の注入圧力を直 接測定する11),18)ことが挙げられる. 特に，後者の方法は 有用であり，最近ではかなり一般的な技術になりつつあ る.

損失水頭に関するその他の注意事項としては，注入管 内の十分な空気抜きが挙げられる ${ }^{19)}$.つまり，注入管へ の空気の混入により，水が注入管内を満管で流れないた めに注入圧力や注入量のデータがばらついたり大きな管 内抵抗となる.なお，この空気混入の有無を，注入管を 一部アクリルパイプにすることにより目視で確認するこ とも有効な対策の 1 つである.

c）注水に伴う地下水面上昇の影響播田・豊田 ${ }^{18}$ は, 新第三紀の堆積岩に対する地下水面下のルジオンテ ストにおいて, 試験後の地下水位が試験前のそれよりも 高くなる場合が多かったと報告している．注水に伴い地 下水面が上昇する (Fig. 8 参照) と, 有効注入圧力が減 少し, 結果的に $p-q$ 曲線の形状に何らかの影響を与え るものと考える.これを浸透流解析により確認する.

まず, 地下水面を固定した解析と, 実際の現象に合わ せて地下水面の上昇を許した解析で注入量にどの程度の

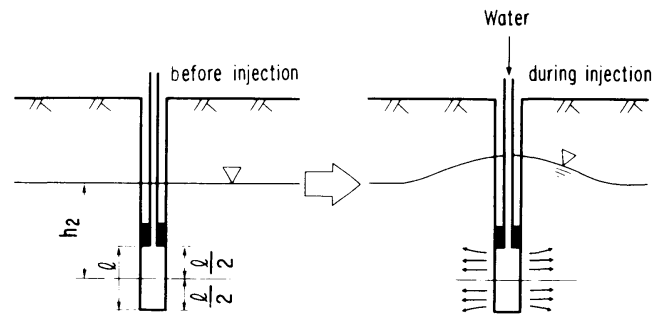

Fig. 8 Rise of ground water table due to water injection.

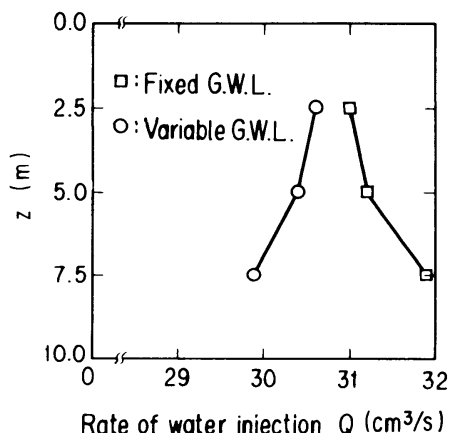

Fig.9 Relationship between $z$ and $Q$. 
差が出るかを示したのが Fig.9である.なお，有効注入 圧力 $p$ は $0.4 \mathrm{kgf} / \mathrm{cm}^{2}$ とした。この図から，前者の注入 量の方が後者のそれよりも大きいが，その差は最大の $z$ $=7.5 \mathrm{~m}$ のときで約 $7 \%$ टさほど大きくないうえ, 注 水前の地下水面が高いほど小さくなっていることがわか る.これは，注水に伴う地下水面の上昇が有効注入圧力 減少に与える影響は，地下水面か試験区間に近いほど大 きいが，大きな注入量の減少をもたらすほどのものでは ないことを示唆している。.また, 浸透流解析より求めた $z=7.5 \mathrm{~m}$ のときの $p$ - $q$ 曲線を Fig. 10 に示す. この図 より，注水に伴う有効注入圧力低减の影響が最大である $z=7.5 \mathrm{~m}$ のときの $p-q$ 曲線でも原点を通る直線となっ ている. よって, ルジオン値を求める際の問題はないこ とがわかる。なお，上記浸透流解析の対象地盤は，明ら かにDarcy 則の成り立つ軟岩および砂碟地盤である.

一方の硬岩地盤内浸透流は亀裂の方向・分布に支配さ

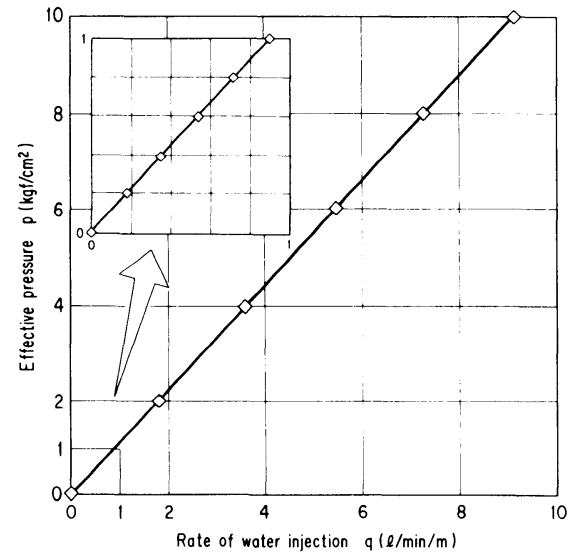

Fig. $10 p$ - $q$ curve at $z=7.5 \mathrm{~m}$.

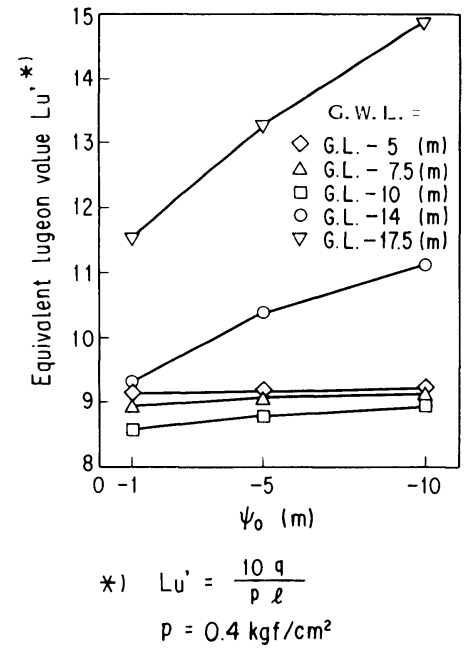

Fig. 11 Relationship between $\psi_{0}$ and $L u^{\prime}$.
れ，注水による試験孔周辺の地下水面の上昇量を定量的 に予測することは困難である．そのため，一般的な議論 は難しいが，影響度合は上記の結果とさほど大きな差は ないと考える.

d）重力流および不飽和浸透の影響地下水面上の 試験では, 試験孔からの水の流れが重力や地盤の不飽和 特性の影響を受け，原点を通る直線型ではない $p-q$ 曲 線が得られると考える.これを浸透流解析により確認す る.

まず, 地下水面の位置, $p, \psi_{0}$ を種々に変えて解析し て求まった注入量（換算ルジオン值）を Fig. 11，12 に 示す．これらの図面から，試験孔からの水の流れが重力 や不飽和特性の影響をほとんど受けない地下水面下での 注入量に比へ，それらの影響をかなり受ける地下水面上 での注入量は大きくなる，また，その傾向は， $\psi_{0}$ が大 きいほど， $p$ が小さいほદ゙，また地下水面が低くなるほ ど強くなる。この傾向は, Stephen and Neuman ${ }^{20)}$, Philip ${ }^{21}$ らの研究結果に一致する.

$p-q$ 曲線の形状に着目すると, 地下水面下の試験で は原点を通る直線型であるのに対して, 地下水面上での 試験では重力や地盤の不飽和特性の影響により逐次流量 減少型となる．また，ダム湛水後の基礎浸透流は明らか にポテンシャル流である．よって，基礎浸透流を支配す る透水性は，ポテンシャル流が達成できる地下水面下で の試験より求まるルジオン值で表現できるのであり，地 下水面上の試験から得られるルジオン值はそれよりも大 きい，しかし，その差は，地盤の不飽和特性（本解析で は $\phi_{0}$ しか変化させていない), 注入圧力, 地下水面の位 置に左右されるため，ここでそれらすべてを考慮してそ の差を定量的に示すことは困難である．ただ，地下水面 上での試験においてより真に近いルジオン值を求めるた

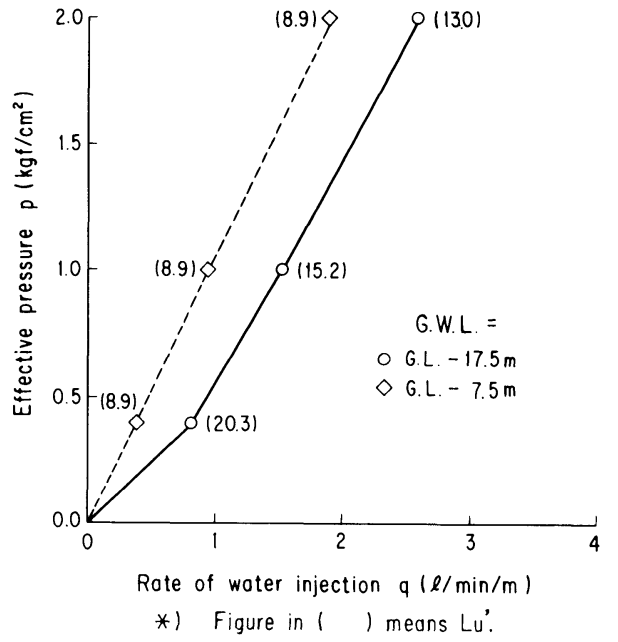

Fig. $12 p$ - $q$ curves under two ground water level conditions. 
めの対策としては, Fig. 12 からもわかるとおり，なる ベく大きい注入圧力で試験を行うほか, 地盤の不飽和特 性についても, 今後, ダムサイトごとに検討を加えてい くことが挙げられる.

\section{（3）昇降圧段階異路の場合の詳細検討}

a) 目詰りの影響試験孔掘削時に発生するスライ ムの洗浄不足や試験水中の浮遊物により試験孔周辺地盤 の亀裂あるいは間隙の目詰りが助長され, 試験が進むに つれて見掛け上透水性が減少するため逐次流量減少型で 昇降圧段階異路の $p-q$ 曲線が得られることがある ${ }^{11), 12)}$. 対策としては, 試験前に十分な孔内洗浄を行ったり ${ }^{11}$, 極力清浄な水を利用して試験を実施したり，注入圧力段 階を減少することなどが考えられる，ただし，長時間の 孔内洗浄は時間の口スになるうえ, 試験対象地盤が軟岩 や砂碩で構成されている場合は, 長時間洗浄が地盤侵食 につながる可能性もあるので注意を要する.よって，ダ 么基礎調查の初期段階に, 対象地盤はよ゙の程度の時間を かけて孔内洗净を行えば, 目詰りも侵食も発生しない地 盤なのかを検討しておくことも 1 つの対策となろう ${ }^{221}$.

上記に示す対策を講じたにもかかわらず，目詰りが原 因亡考えられる $p-q$ 曲線が得られた場合は, 昇圧段階 の初期接線勾配直線をもとにルジオン值を求めるべきで
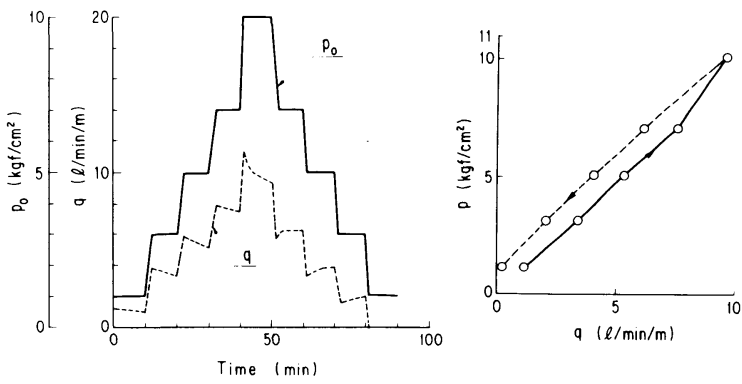

Fig. $13 p_{0}$ and $q$ with time and $p$ - $q$ curve.

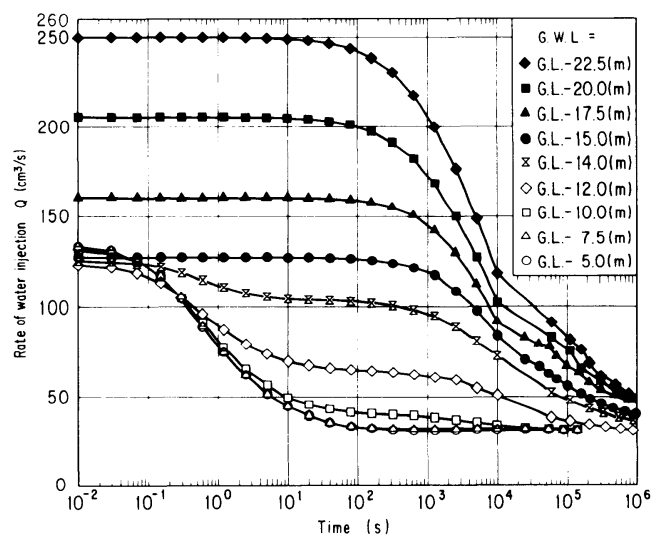

Fig. 14 Effect of ground water level $\left(p=0.4 \mathrm{kgf} / \mathrm{cm}^{2}\right)$.
ある・

b) 非定常の影響透水性が小さく, 貯留能力（変 形性）の大きい地盤に対して試験を実施する際，技術指 針に示された「注入量の測定時間は原則として 5 分間と するが，その間の 1 分ごとの注入量を測定し, 変動が小 さい（通常 $10 \%$ 未満）ことを確認する必要がある」と いう注入量测定法に従うと, Fig. 13 に示すような昇降 圧段階異路の逐次流量減少型 $p-q$ 曲線が得られる場合 がある. 対策としては, 各圧力段階で定常注入量が得ら れるまで長時間注水することが挙げられる ${ }^{23), 24)}$. しかし， 目詰りの影響のところで示したのと同様の理由から，基 礎調査の初期段階において長時間のルジオンテストを実 施し，どの程度の時間通水すれば目詰りの影響もなく定 常注入量が得られるのか, また, 通常の仕様により注入 量の測定を実施した場合には真のルジオン值とはどの程 度の差でルジオン值を求めることになるのかを確認して おくことが肝要となろう。なお，非定常の影響により昇 降圧段階異路の逐次流量減少型 $p-q$ 曲線が得られた場 合は, Fig. 13 に示した $p, q$ の経時曲線において昇圧時

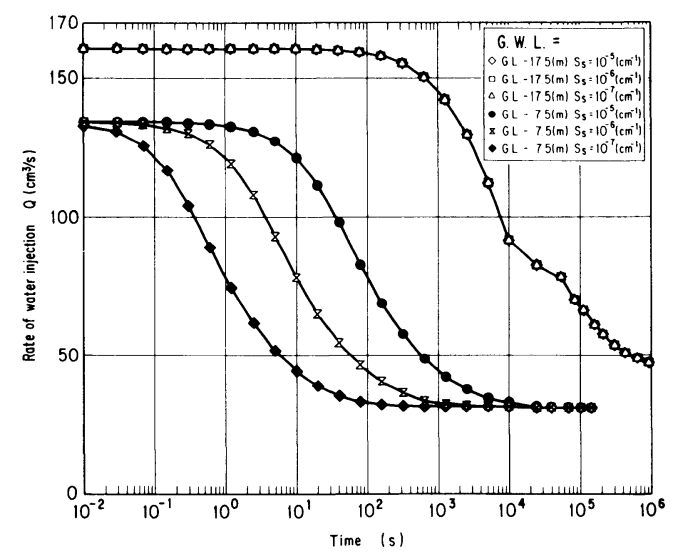

Fig. 15 Effect of $S_{s}\left(p=0.4 \mathrm{kgf} / \mathrm{cm}^{2}\right)$.

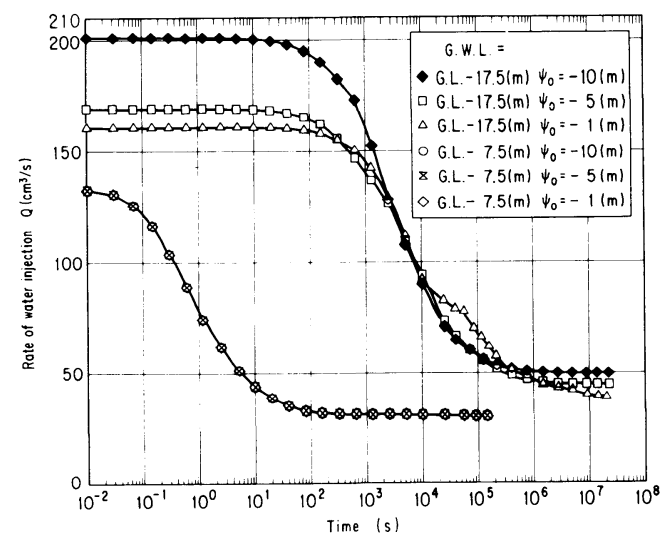

Fig. 16 Effect of $\psi_{0}\left(p=0.4 \mathrm{kgf} / \mathrm{cm}^{2}\right)$. 
は $q$ が逐次減少し, 降圧時は逐次增加していることか ら判断して原点と最高注入圧力点を結んでルジオン值を 求めるのがよかろう.

次に, 式（5）の基本方程式を参考に地下水位, 比貯 留係数 $S_{s}, \psi_{0}$ を種々に変化させて非定常浸透流解析を 行い定常注入量が得られるまでに要する時間を検討し た. その結果を Fig. 14〜16に示す.

これらの図から, 地下水面下の試験においては定常注 入量が得られる時間 $t$ は $S_{s}$ が大きいほど長いが, $C(\theta)$ には全く関係なく, 地下水面上の試験では $C(\theta)(=$ $\partial \theta / \partial \psi)$ が大きいほど長いが， $S_{s} に は$ 全く関係ない(本 モデル解析において $C(\theta) \gg S_{s}$ である影響もあろうが $)$ ことがわかる. また, 基本方程式から, $k$ が小さいほど $t$ が長くなることも容易に推察がつく.

西垣 ${ }^{25)}$ は, 上記と同様の計算を行い, $t$ と $S_{s}, k$ の 関係を次式として示している.

$$
t=60000\left(S_{s} / k\right) \quad(\mathrm{s})
$$

今回の解析結果に対しても上式はほぼ成立する.また, 地下水面上の試験においても, 今回の解析では, $C(\theta)$ $\gg S_{s}$ ということもあり(ただし，実地盤を考えた場合 極端におかしい設定ではない)，式（7）の $S_{s}$ を $C(\theta)$ に置換した条件式がほぼ成立する，ルジオンテストを実 施する前に $k, S_{s}$ 等の係数值を知ることは困難である が, 地盤の状況なざをよく観察したうえで, 不飽和特性 についての研究成果 ${ }^{26)}$.27) も参考に $t$ を概略算定してお くことも重要となろう.

\section{7. 逐次流量増加型 $\boldsymbol{p}-\boldsymbol{q}$ 曲線}

\section{（1）発生原因}

これは, Fig.6（f），（g）に示すように昇圧段階に おける初期接線勾配直線に比較して流量が逐次増加傾向 にある $p-q$ 曲線のことで, 逐次流量減少型と同様に, 昇降圧段階同路のもの（Fig.6（f）参照）之昇降圧段 階異路のもの（Fig.6（g) 参照）に分類できる.なお,
昇降圧段階異路のものは, 同じ注入圧力であれば昇圧段 階の注入量の方が降圧段階のそれよりも小さいと考えて も差し支えない.この型の $p-q$ 曲線が発生する原因を 以下にまとめる.

\section{(昇降圧段階同路)}

(1) 注入管内抵抗による損失水頭 $h_{3}$ を過大評価して いる場合.

（2）水圧載荷に伴い地盤中の潜在亀裂を含めた亀裂が 開いたり, 地盤構成粒子に浮力が作用して地盤の間 隙が広がるものの, 水圧除荷とともに元の状態に戻 る場合.

(昇降圧段階異路)

(1) 水圧載荷に伴い地盤中の潜在亀裂を含めた亀裂が 開いたり, 地盤構成粒子に浮力が作用して地盤の間 隙が大きくなり, かつ水圧除荷によっても元の状態 に戻らない場合.

(2) 水圧載荷に伴い地盤亀裂中の挟在物や地盤構成粒 子が徐々に洗い流される場合.

\section{（2）昇降圧段階同路の場合の詳細検討}

a）損失水頭の影響 損失水頭を過大評価した場 合には, 過小評価あるいは無補正の場合とは逆に昇降圧 段階同路の逐次流量増加型の $p-q$ 曲線が得られる. 対 策は，損失水頭の過小評価あるいは無補正の場合と同じ である.

b) 可逆変形の影響 ルジオンテストにおける水圧 載荷に伴い地盤中の潜在亀裂も含めた亀裂が開いたり, 地盤構成粒子に浮力が作用して地盤の間隙が大きくなる ため水圧増加に伴い地盤の透水性が見掛け上徐々に大き くなり, 結果として逐次流量增加型の $p-q$ 曲線が得ら れる. ただし, 地盤の変形が可逆的である範囲では, 水 圧除荷に伴い地盤は元の状態に戻り, 昇降圧段階同路の $p-q$ 曲線となる.

通常, この型の $p-q$ 曲線が得られた場合は安全側と いうことも考慮して, 原点と最高圧力点を結んだ直線よ

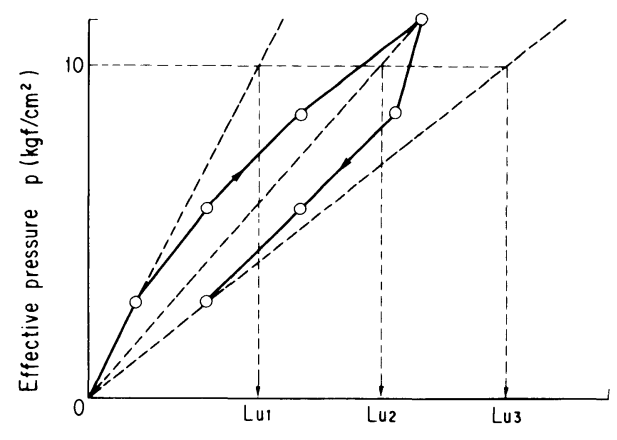

Rate of water injection $q(\ell / \mathrm{min} / \mathrm{m})$

Fig. 18 Determination of Lugeon value.

Fig. 17 Determination of Lugeon value. 
りルジオン值 $L u_{2}$ (Fig. 17 参照) を求める場合が多い. しかし，ダム湛水時には基礎地盤にルジオンテスト時の ような局所的な水圧載荷がなされないうえ，堤体の上載 荷重も地盤の浮き上がりを押さえる方向に作用する. よって, 水圧増加に伴い逐次透水性が増加するのが亀裂 中挟在物や地盤構成粒子の流亡によるのではなく可逆的 な変形挙動による場合には，堤体荷重等を定量的に評価 したうえで $p-q$ 曲線の初期接線勾配直線より求まるル ジオン值 $L u_{1}$ （Fig. 17 参照）を採用することも可能と なる。

\section{（3）昇降圧段階異路の場合の詳細検討}

水圧載荷に伴い地盤中の潜在的亀裂も含めた亀裂が開 いたり，地盤構成粒子に浮力が作用して地盤の間隙が大 きくなり, かつ地盤変形が非可逆的である場合，あるい は, 亀裂中の挟在物や地盤構成粒子が徐々に洗い流され る場合に, 昇降圧段階異路の逐次流量増加型の $p-q$ 曲 線が得られる.この型の $p-q$ 曲線からは, 以下の 3 種 類の方法でルジオン值を決定することが考えられる.

(1) 昇圧段階の初期接線勾配直線よりルジオン值

（Fig. 18 の $L u_{1}$ ）を決定する方法.

(2) 原点と最高圧力点を結んだ直線よりルジオン值 （Fig. 18 の $L u_{2}$ ）を決定する方法.

(3) 原点と最終圧力点を結んだ直線より求まる最高ル ジオン值（Fig. 18 の $L u_{3}$ ）を採用する方法.

ルジオンテスト孔からの水の流れが放射流であるのに 対して，ダム湛水に伴う基礎浸透流はほぼ一次元流であ る. そのためルジオンテストにおいて発生した非可逆的 変形, 地盤構成粒子の流亡がダム湛水時の基礎浸透流に よっても発生するか否かを判定することは非常に困難で ある. よって， $L u_{1}$ を採用することの理由付けも困難 となる. 以上より, この場合は, 安全側という判断も付 け加えて, $L u_{2}$ ないし $L u_{3}$ をルジオン值として採用し ておく方が無難だといえる.

\section{8. その他の $\boldsymbol{p}-\boldsymbol{q}$ 曲線}

\section{（1）原点を通らない直線型 $\boldsymbol{p}-\boldsymbol{q}$ 曲線}

Fig. 6 （h）に示すように，得られた $p, q$ には直線関 係があるが，その直線が原点を通らない場合がある.こ の型の $p-q$ 曲線の主な発生原因は, ルジオンテストに おいて, 一般に「通常毎朝作業開始前の試験孔内水位を 測定し,この水位を試験時の地下水位とみなす」成こと による誤差であると考える.つまり, 宙水や被圧地下水 などの存在により, 地盤内の地下水圧分布が静水圧分布 に従わない場合には, 上記の方法により正確な地下水圧 を知ることはできないということである.

対策としては, 試験結果の数がある程度出そろった時 点で地下水位分布の洗い直しを行うか, 前述したように
試験区間内に間陌水圧計を設置して，地下水位ではなく 地下水圧を試験前に直接とらえること等が挙げられる.

また,この $p^{-} q$ 曲線を逐次流量減少型の $p-q$ 曲線と 見誤る可能性があるので十分な注意が必要である.

\section{（2） 2 段勾配 $\boldsymbol{p}-\boldsymbol{q}$ 曲線}

Fig. 6 （i ）に示すような 2 段勾配 $p-q$ 曲線の発生原 因としては, 試験孔の水洗い不足やある珐力以上での亀 裂の開口等が考えられる. しかし, 発生原因により初期 直線からルジオン值を求めるべき（亀裂の開口）か, 折 れ曲がり後の直線部分から求めるべき（水洗い不足）か が異なるので, 試験時の水洗い状況や地盤状況を総合的 に判断してルジオン值を決定すべきである.

\section{（3）緩勾配 $\boldsymbol{p}-\boldsymbol{q}$ 曲線}

一口に緩勾配といっても，それを定義することは非常 に困難である．よって，以下に示す原因により発生する $p-q$ 曲線を緩勾配 $p-q$ 曲線とよぶことにする (Fig. 6

(j) 参照).

(1) 透水性の非常に大きい亀裂性岩盤における試験 で, ポンプ容量が不足して有効注入圧力が上がりに くい場合.

(2) 亀裂の少ない軟岩や砂碩地盤のように限界圧力が 小さい地盤に対する試験で, 第一段階の水圧やポン プ脈動に伴う水圧変動が大きいため地盤が破壊さ れ，その後の透水性を評価してしまう場合 (1),4),28),291. (1)に示すような地盤において正確にルジオン值を求め るためには，試験区間長を短くしたり，注入圧力を小さ くすることにより注入量を低減さすか, 前述した高粘性 流体試験を実施することが望ましい，ただし，ポンプ容 量を上げて, 試験区間長や注入圧力を変化させないのは 良策ではない。

(2)に示すような地盤において正確にルジオン值を求め るためには, 脈動の小さいポンプを用いるか, ポンプに 高容量のエアチャンバを取り付けるか, 静水圧による載 荷等を利用することにより，注入圧力を高精度に制御し たうえで微増させてルジオンテストを実施するととも に, ピット孔等を利用した他の原位置透水試験を併せて 実施してルジオンテストの結果を検討する4(1)28),29)ことが 望ましい。

\section{9. まと め}

本論文においては，(1)ルジオンテストの結果求まる $p-q$ 曲線をその形状により Fig. 6 に示すように分類し, (2)それらの発生原因を列挙し，(3)さらに発生原因の影響 度合を検討したうえで, (4)ダム基礎浸透流を支配する透 水性を表わすルジオン值を求めるための対策を示した. すなわち，ルジオンテストに際しては，地下水圧測定や 注入管抵抗による損失水頭の補正の精度を上げて有効注 
入圧力を正確に把握し，かつ注入量の非定常現象, 注水 に伴う目詰り現象や地盤の変形, 破壊に十分留意しなが ら注入量を測定したうえで $p-q$ 曲線を描き，最終的に は試験区間が地下水面の上にあるか下にあるか, あるい は注入した水の流れが層流か乱流であるかを分析してル ジオン值を決定することが望まれる.

実際の現場試験において得られる $p-q$ 曲線には, 本 論文で示した以外の形状をもつものを見掛けることもあ る.こうした $p-q$ 曲線は, 本論文で示した各形状の $p-q$ 曲線の発生原因の複数が作用することにより発生 するものと考える. よって, そのような $p-q$ 曲線が発 生する場合でも, 本論文で示した各種 $p-q$ 曲線の発生 原因の影響度合を考慮したうえで, 各種対策を施すこと により，かなり正確にルジオン值を求めることができる ものと考える.

謝辞：本研究を遂行するにあたり，株式会社間組 の弘末文紀氏には飽和不飽和浸透流解析について, また 日特建設株式会社の渋市秀雄氏には高粘性流体試験につ いて多大なるご協力を賜った．末筆ながら記して感謝の 意を表します。

\section{参 考文 献}

1）建設省河川局開発課監修：ルジオンテスト技術指針・同 解説，(財）国土開発技術センター, 1984 年 6 月.

2）菅原利夫：軟岩の透水性把握に関する問題, 土と基礎, Vol. 35, No. 4, pp. 23〜29, 1987 年 4 月.

3) Lugeon, M. : Barrages et géologie, Dunod, Paris, 1933.

4）松本徳久・山口嘉一：地下深部の軟岩地盤に対するルジ オンテスト, 第 7 回岩の力学国内シンポジウム講演論文 集, 岩の力学連合会等, pp. 223 228, 1987 年 12 月.

5）松本徳久・山口嘉一・弘末文紀：ルジオンテストの各種 境界条件下での精度と結果の解釈，建設省土木研究所資 料, 第 2518 号, pp. 4 7, 1987 年 11 月.

6）赤井浩一・大西有三・西垣 誠: 有限要素法による飽和不飽和浸透流の解析, 土木学会論文報告集, 第 264 号, pp. 87 96, 1977 年 8 月.

7）松本徳久・山口嘉一：異方性地盤における原位置透水試 験方法に関する研究, 建設省土木研究所資料, 第 2373 号, pp. 19 21，1986 年 5 月.

8) Irmay, S. : On the hydraulic conductivity of unsaturated soils, Trans. Amer. Geophys. Union, Vol. 35 ( 3 ), pp. 463 467, 1954.

9）末吉治彦，ほか：節理性岩盤における乱流状況と透水性 評価, 第 18 回岩盤力学に関するシンポジウム講演論文集, 土木学会岩盤力学委員会, pp. $356 \sim 360,1986$ 年 2 月.

10）前掲 5), pp. 88 96.

11) Kutzner, C. : Considerations on rock permeability and grouting criteria, Proceedings of the 15 th Congress on
Large Dams, Question 58, pp. 315 328, 1985.

12) Ewert, F.K. : Rock Grouting with Emphasis on Dam Sites, Springer-Verlag, 1985.

13) Houlsby, A.C. : Routine interpretation of the Lugeon water-test, Journal of Engineering Geology, Vol.9, pp. 303 313, 1976.

14) Lancaster-Jones, P.F.F. : The interpretation of the Lugeon water-test, Journal of Engineering Geology, Vol. 8, pp.151 154, 1975.

15）渡辺邦夫・芦川亮一：割れ目岩盤の透水試験における乱 流の影響評価の試み, 第 17 回岩盤力学に関するシンポジ ウム講演論文集, 土木学会岩盤力学委員会, pp. 161 165, 1985 年 2 月.

16）松本徳久・山口嘉一・渋市秀雄：高粘性流体を用いた透 水試験, 第 23 回土質工学研究発表会講演集, pp. 125 126,1988 年 6 月.

17）前揭 5), pp. 104 106.

18）播田一雄・豊田光雄 : 水圧計を利用したルジオンテスト における一考案，建設省土木研究所資料，第 1570 号， 1980 年 3 月.

19）桑原啓三：ルジオンテスト施工指針（案）の検討, 建設 省土木研究所資料, 第 1907 号, pp. 11 19, 1983 年 3 月.

20) Stephens, D. B. and Neuman, S. P. : Free surface and saturated-unsaturated analyses of borehole infiltration tests above the water table, 3 rd International Conference on F.E. in Water Resources, Univ. of Mississippi, Oxford, pp. 2229 2238, 1980.

21) Philip, J. R. : Approximate analysis of the borehole permeameter in unsaturated soil, Water Resources Research, Vol.21, No.7, pp. 1025〜1033, 1985.

22）松本徳久・山口嘉一：風化岩基礎における原位置透水試 験の適用性について, 原位置透水試験法および地下水調 査に関する発表論文集, pp. 65 70, 1985 年 12 月.

23）振井茂宏, ほか：第四紀砂喽層におけるグラウト効果の 評価について, 第 40 回建設省技術研究会講演概要, 自由 課題, 河川部門, pp. 13 20, 1986 年 10 月.

24）中村康夫：ボーリングに伴う情報一水の情報一, 建設省 土木研究所資料, 第 2221 号, pp. 99 112, 1985 年 3 月.

25) 西垣 誠: 単孔式透水試験の問題点の対策と改良, 地下 水と井戸とポンプ, Vol.28, No. 9, pp.1 10, 1986 年 9 月.

26）向上拡美・北村孝海：浸透流における不飽和特性と解析 精度に関する考察, 間組研究年報, pp. 163 174, 1986 年.

27）西垣 誠・楠見和紀：不飽和土の透水特性の推定法, 第 22 回土質工学発表会講演集, pp. 1555 1556, 1987 年 6 月.

28）松本徳久・山口嘉一：軟岩基礎の原位置透水試験方法に 関する研究, 第 17 回岩盤力学に関するシンポジウム講演 論文集, 土木学会岩盤力学委員会, pp. 201 205, 1985 年 2 月.

29）松本徳久・山口嘉一：軟岩基礎の原位置透水試験方法に 関する考察，土木技術資料，Vol. 27, No. 10, pp. 3 8, 1985 年 10 月.

(1989.1.12 - 受付) 